\title{
DEMOGRAFSKE IN SOCIALNE ZNAČILNOSTI OBČIN SPODNJEGA POSAVJA NA OSNOVI MODELA TRAJNOSTNEGA RAZVOJA NA LOKALNI RAVNI
}

Saša Založnik, univ. dipl. geografinja

Gubčeva 6, SI-8270 Krško

e-mail: sasazaloznik@gmail.com

Izvirni znanstveni članek

COBISS 1.01

\section{Izvleček}

$\mathrm{V}$ članku so analizirane izbrane socialne in demografske značilnosti občin Spodnjega Posavja na osnovi modela trajnostnega razvoja na lokalni ravni. Cilj članka je predstaviti omenjeni model ter njegove prednosti in slabosti v primerjavi z ostalimi načini merjenja trajnostnega razvoja na lokalni ravni. Izbrani socialno-demografski del modela predstavlja del nadgradnje dosedanjim modelom trajnostnega razvoja na tem nivoju.

Ključne besede: trajnostni razvoj, model trajnostnega razvoja na lokalni ravni, demografska struktura prebivalstva, občina, Spodnje Posavje, Slovenija

\section{DEMOGRAPHIC AND SOCIAL CHARACTERISTICS OF THE MUNICIPALITIES OF SPODNJE POSAVJE REGION BASED ON A MODEL OF SUSTAINABLE DEVELOPMENT AT A LOCAL LEVEL}

\begin{abstract}
The paper analyses selected social and demographic characteristics of municipalities in the Spodnje Posavje region based on a model of sustainable development at a local level. The main aim of the article is to present the model, its advantages and disadvantages in comparison to other methods of measuring sustainable development at the local level. Selected socio-demographic part of this model presents additional contribution to the previous models of sustainable development at this level.
\end{abstract}

Key words: sustainable development, model of sustainable development at a local level, demographic characteristics, municipality, Spodnje Posavje, Slovenia 


\section{I.UVOD}

Poznamo več različnih modelov merjenja trajnostnega razvoja, kot so zeleni BDP, trajnostni nacionalni dohodek, kazalci trajnostnega razvoja za Slovenijo, ekološke sledi, indeks boljšega življenja, modeli raziskovanja okolja in okoljskih virov DPSIR ter številni drugi. Vendar pa večina do sedaj znanih modelov vsebuje kazalce, ki so prilagojeni globalnemu, deloma tudi regionalnemu nivoju. Ker se želimo v raziskavi spustiti na lokalni nivo, smo za predstavitev demografskih in socialnih značilnosti občin Spodnjega Posavja uporabili model trajnostnega razvoja na lokalni ravni.

Glavni namen članka je predstaviti model trajnostnega razvoja na lokalni ravni kot primer metodologije za opredelitev stopnje in trendov razvoja posameznih občin na območju Spodnjega Posavja na okoljskem, ekonomskem in socialnem področju, ki bo služil kot osnova nadaljnjim raziskavam za izdelavo geografske zasnove trajnostnega razvoja teh občin.

V drugem delu bo bolj podrobno predstavljen del tega modela, na podlagi katerega bomo prikazali izbrane demografske in socialne značilnosti vseh štirih občin obravnavanega območja. Omenjeni del modela, ki bo tudi praktično preizkušen na primeru izbranih socialnih in demografskih značilnosti posameznih občin, je bil izbran, ker predstavlja del nadgradnje Plutovega (2004) modela preučevanja okolja in njegovih sestavin za sonaravno usmerjanje prostorskega razvoja, iz katerega izhaja.

\section{MODEL PREUČEVANJA TRAJNOSTNEGA RAZVOJA NA LOKALNI RAVNI}

V literaturi je o trajnostnem razvoju nasploh in o njegovem uvajanju v posamezne dejavnosti človekovega življenja precej napisanega, o sami metodologiji, ki je bila uporabljena pri izdelavi Lokalnih agend 21 za posamezna območja, pa so podatki skromni.

Zato je bil za analizo stanja in trendov okoljskega, ekonomskega in socialnega razvoja kot osnove za geografsko zasnovo trajnostnega razvoja Spodnjega Posavja izdelan model preučevanja trajnostnega razvoja na lokalni ravni, ki predstavlja nadgradnjo Plutovega (2004) modela preučevanja okolja in njegovih sestavin za sonaravno usmerjanje prostorskega razvoja, saj vključuje tudi prikaz socialno-ekonomskega stanja in razvojnih trendov. $\mathrm{Na}$ ta način so v model vključeni tudi podatki o človeških in gospodarskih virih obravnavanega območja, ki predstavljajo enega od temeljev izdelave geografske zasnove nadaljnjega razvoja območja v skladu z načeli trajnosti.

Vsakega od delov modela sestavljajo posamezni kazalci, ki so prilagojeni obravnavanim prostorskim enotam in ambiciji po uporabnosti tudi v podobnih raziskavah v drugih regijah. Izbor teh kazalcev je vedno vsaj deloma subjektiven, saj že njihova izbira sama temelji na subjektivnem prepričanju posameznika ali skupine, da so pomembni za merjenje določene razsežnosti trajnosti. Pri izboru kazalcev smo upoštevali osnovna merila, kot so relevantnost kazalca za politiko in odločanje, enostavnost, nedvoumnost glede želene smeri gibanja kazalca (zelo priporočljiv je obstoj referenčne ali mejne vrednosti), primerljivost izračunov na različnih prostorskih ravneh, občutljivost na zaznavanje sprememb v času in prostoru ter med skupinami v družbi, enostavnost in stroškovno sprejemljiva dostopnost kakovostnih 
podatkov za čim daljše časovne nize. Pomembno je tudi povezovanje kazalcev v sistem, saj to večinoma niso kazalci, razviti posebej v ta namen, ampak so primarno okoljski, ekonomski ali socialni kazalci, ki sami po sebi niso pokazatelji trajnosti in šele kot sistem dobijo svojo pojasnjevalno vrednost (Vintar Mally, 2006).

\section{Preglednica 1: Model trajnostnega razvoja na lokalni ravni}

Table 1: Model of sustainable development at a local level

\begin{tabular}{|c|c|c|}
\hline \multicolumn{3}{|c|}{ Krajevne skupnosti / Spodnje Posavje } \\
\hline Socialno-ekonomski podsistem & & Okoljski podsistem \\
\hline $\begin{array}{l}\text { Socialno-ekonomsko stanje, } \\
\text { razvojni trendi } \\
\text { - demografske in socialne } \\
\text { značilnosti prebivalstva } \\
\text { - ekonomsko stanje in trendi } \\
\text { razvoja } \\
\text { Viri pritiskov na okolje } \\
\text { - poselitev z gospodarstvom } \\
\text { (mesta in druga strnjena naselja, } \\
\text { industrija, rudarstvo itd.) } \\
\text { - infrastruktura (promet, } \\
\text { energetika, komunalna } \\
\text { opremljenost itd.) } \\
\text { - pokrajinska raba (gozdarska, } \\
\text { kmetijska, rekreacijska itd.) }\end{array}$ & $\begin{array}{c}\leftarrow \text { Pritiski } \rightarrow \\
\text { Poraba naravnih virov } \\
\text { (surovin, energije), } \\
\text { raba zemljišč, emisije } \\
\leftarrow \text { Vplivi } \rightarrow \\
\text { Na bivalno okolje } \\
\text { (zdravje ljudi, škoda v } \\
\text { antropogenih in naravnih } \\
\text { sestavinah okolja); } \\
\text { na naravne vire; } \\
\text { naravo } \\
\leftarrow \text { Odzivi } \rightarrow \\
\text { Kurativni in preventivni } \\
\text { ukrepi in instrumenti } \\
\text { prostorske politike }\end{array}$ & $\begin{array}{l}\text { Stanje, trendi kakovosti okolja } \\
\text { - oblike, obseg in spremenljivost } \\
\text { kakovosti } \\
\text { - stopnja onesnaženosti - imisije } \\
\text { - stanje in spremembe v } \\
\text { večletnem obdobju } \\
\text { - stanje in spremembe med } \\
\text { letom - sezonske, dnevne, } \\
\text { urne vrednosti, preseganje } \\
\text { mejnih in kritičnih vrednosti } \\
\text { itd. } \\
\text { Občutljivost (nevtralizacijske } \\
\text { in regeneracijske sposobnosti) }\end{array}$ \\
\hline
\end{tabular}

Veliko število kazalcev, ki sestavljajo model trajnostnega razvoja na lokalni ravni, je ena od glavnih slabosti tega modela, saj je interpretacija rezultatov v tem primeru težja kot če imamo opravka zgolj z enim sinteznim kazalcem. Prednost tako zasnovanega modela pa je, da poleg stanja in trendov ter občutljivosti posameznih okoljskih sestavin vključuje tudi pomembnejše pritiske na okolje in njihove vire, kakor tudi odzive na okoljske probleme, dodatno pa je nadgrajen še s socialno-ekonomskimi vidiki in trendi razvoja. Vsi ti deli nam dajejo zaokrožen pogled na obravnavano območje, ki je potreben za izdelavo konkretnih predlogov in smernic nadaljnjega razvoja v skladu z načeli trajnosti.

\section{KAZALCI DEMOGRAFSKIH IN SOCIALNIH ZNAČILNOSTI PREBIVALSTVA}

Socialno področje predstavlja eno od treh temeljnih področij trajnostnega razvoja, saj ga že definicija Brundtlandine komisije poudarja kot enega od ciljev trajnostnega razvoja, katerega cilj ni le zadovoljevanje potreb sedanje, temveč tudi prihodnjih generacij, pri čemer je potrebno pojave, kot so družbena izključenost, neenake možnosti, revščina in kriminal, zmanjšati na minimum (Berdavs, 2007).

Načelo trajnostnega razvoja kot najpomembnejši vrednoti na socialnem področju izpostavlja socialno varnost in pravičnost. Vsem prebivalcem je namreč potrebno omogočiti 
čim bolj enakovredne pogoje za življenje in delo, tako da lahko uresničujejo svoje sposobnosti in ideje ter doprinesejo k endogenemu razvoju svojega kraja, občine, regije (Vintar, 2002).

Socialni kazalci so se začeli pogosteje uporabljati v 60. letih preteklega stoletja v povezavi z željami, da bi izmerili napredek pri zdravju, prehranjevanju, razdelitvi dohodka, bivanju in drugih vidikih življenja. Pomen kakovosti življenja se je vedno bolj širil, življenjski standard ali materialno blaginjo pa se je začelo omejevati predvsem na materialno plat človekove kakovosti življenja. Zaradi številnih metodoloških problemov in odsotnosti širše sprejetega sporazuma o modelu povezav med zapletenimi in večdimenzionalnimi socialnimi pojavi pa do oblikovanja enotnega socialnega sistema in s tem agregatnega kazalca ni prišlo (Seljak, 2000). Zato je za prikaz demografskih in socialnih značilnosti prebivalstva potrebno uporabiti večje število individualnih kazalcev, da dobimo bolj reprezentativen prikaz posameznih področij socialnega razvoja. V skladu z načeli trajnostnega razvoja naj bi ti kazalci prikazovali predvsem osnovne značilnosti prebivalstva, standard bivanja, dostop do zdravstvene oskrbe in izobraževanja, socialno izključenost, dohodkovne razlike, enakopravnost med spoloma in podobne vidike (Vintar Mally, 2003).

Preglednica 2: Izbrani kazalci demografskih in socialnih značilnosti prebivalstva Table 2: Selected indicators of demographic and social characteristics of population

\begin{tabular}{|c|l|l|}
\hline & Izbrani kazalci & Področje \\
\hline 1 & Število in trendi spreminjanja števila prebivalcev & Osnovne značilnosti prebivalstva \\
\hline 2 & Koeficient starostne odvisnosti & Osnovne značilnosti prebivalstva \\
\hline 3 & Gostota poselitve & Koncentracija prebivalstva \\
\hline 4 & Izobrazbena sestava prebivalstva & Dostop do izobrazbe \\
\hline 5 & Stopnja registrirane brezposelnosti & Revščina \\
\hline 6 & Delež brezposelnih s prvo in drugo stopnjo izobrazbe & Socialna izključenost \\
\hline 7 & Delež žensk med registriranimi brezposelnimi & Enakopravnost med spoloma \\
\hline
\end{tabular}

Rast prebivalstva je odvisna tako od naravnega kot od selitvenega gibanja prebivalstva. Agenda 21 izpostavlja prebivalstveno rast kot eno glavnih dolgoročnih groženj trajnostnemu razvoju, predvsem v povezavi z revščino, omejenimi naravnimi viri ter netrajnostnimi vzorci proizvodnje in potrošnje, še posebej na okoljsko ranljivih območjih (Indicators of sustainable development, 2007). Glede na evropske in tudi slovenske razmere pa izbranega kazalca ne moremo vrednotiti v enaki luči kot na globalni ravni, saj imamo opravka z zelo nizkimi stopnjami prebivalstvene rasti. Z vidika trajnostnega razvoja v Sloveniji je podpovprečna rast oziroma celo upad prebivalstva ovrednotena kot negativen pojav. Posredno nam namreč kaže na (ne)atraktivnost regije za delo in bivanje, (ne)kakovost življenja v njej in depopulacijo posameznih občin in krajevnih skupnosti. Upad števila prebivalstva sicer pomeni manjše pritiske na okolje, a je nesprejemljiv tako z vidika ohranjanja poselitve, preprečevanja nadaljnjega zaraščanja in težnje po ohranjanju kulturne pokrajine, 
kot tudi z vidika koncentracije prebivalstva in naraščanja pritiskov v že tako gospodarsko in prebivalstveno (pre)obremenjenih območjih (Vintar Mally, 2003).

Staranje prebivalstva je pomemben pokazatelj za usmerjanje lokalnega razvoja, predvsem z vidika načrtovanja večjih izdatkov za pokojnine in zadovoljevanja povečanih potreb po zdravstvenem in socialnem varstvu starejših. Starostna struktura prebivalstva prikazuje posledice naravnega in selitvenega gibanja prebivalstva, pa tudi podaljševanja pričakovane življenjske dobe. Staranje prebivalstva $\mathrm{z}$ vidika trajnostnega razvoja vrednotimo kot negativen pojav, še posebej v družbah s starim demografskim režimom, ki ne zagotavljajo več niti enostavne reprodukcije (Vintar Mally, 2003). Koeficient starostne odvisnosti je kot kazalec primeren tudi zaradi možnosti stalnega spremljanja na podlagi demografskih podatkov, ki jih tekoče spremlja statistika.

Agenda 21, eden od temeljnih dokumentov trajnostnega razvoja, povezuje povečevanje gostote poselitve $\mathrm{z}$ dezertifikacijo, problemi zagotavljanja pitne vode, kopičenjem odpadkov v urbanih območjih, ogrožanjem zavarovanih in ekološko občutljivih območij in podobno (Indicators of sustainable development, 1997, str. 49). Za razliko od globalne ravni Slovenija na splošno nima problemov z naraščanjem gostote poselitve, saj ta ostaja v povprečju na isti ravni. Visoka gostota prebivalstva $v$ regiji ali občini se $\mathrm{z}$ vidika trajnostnega razvoja ocenjuje negativno, saj je povezana s povečano rabo naravnih virov, večjimi pritiski na nosilne zmogljivosti okolja ter z večjimi potrebami po zaposlitvi in raznovrstni infrastrukturi, kot tudi reševanju stanovanjske problematike in socialnih problemov (Vintar Mally, 2003).

Izobrazbena sestava prebivalstva je zelo pomembna, saj omogoča posameznikom in družbenim skupinam uresničevanje njihovih potencialov ter omogoča njihovo vključevanje v reševanje razvojnih problemov. Ob spremembah na gospodarskem področju je neprestano višanje izobrazbene sestave prebivalstva skorajda nuja (Berdavs, 2007). Zato z vidika trajnostnega razvoja dvig izobrazbene stopnje prebivalstva vrednotimo kot pozitiven.

Eden od pomembnih ciljev trajnostnega razvoja je tudi zagotavljanje primernih bivališč za vse prebivalce (Indicators of sustainable development, 2007). Pogosto se spremlja s kazalcem koristnih površin $\left(\mathrm{v} \mathrm{m}^{2}\right)$ na prebivalca. Sicer sama površina stanovanj ne pove ničesar o njihovi kakovosti, zato je pri podrobnejših analizah potrebno kazalcu dodati še podatke o velikostni strukturi stanovanj, njihovi starosti, opremljenosti z raznovrstno infrastrukturo in podobno (Vintar Mally, 2003). Lastništvo stanovanj je eden od pomembnih kazalcev dobrega počutja in kvalitete življenja posameznikov, saj lastnike varuje pred nihanjem najemnin in jim daje stabilno in varno zavetje. Pomembna podatka sta tudi število sob po osebi oziroma površina stanovanja na osebo ter osnovni stanovanjski priključki, saj prenatrpana stanovanja lahko negativno vplivajo na telesno in duševno zdravje, odnose z drugimi in razvoj otrok (Indeks boljšega življenja, 2011).

Brezposelne osebe so tiste, ki trenutno ne delajo, ampak so pripravljene za to in aktivno iščejo delo. Dolgotrajna brezposelnost lahko negativno vpliva na počutje in samozavest ter povzroča izgubo sposobnosti in tako zmanjšuje zaposljivost (Indeks boljšega življenja, 2011). Stopnja registrirane brezposelnosti prebivalstva je torej povezana tako s socialnimi kot tudi z ekonomskimi problemi, pogosto tudi z revščino. Kaže tudi na socialno izključenost nekaterih družbenih skupin in na neizkoriščenost človeških virov. Eden od temeljnih ciljev trajnostnega razvoja je tudi izboljšati kakovost življenja vseh ljudi, zato je potrebno odpraviti 
revščino in socialno izključenost. S tega vidika je najučinkovitejša rešitev zagotoviti vsem delovno sposobnim ljudem zaposlitev, saj jim ta daje možnost za zadovoljevanje njihovih potreb in izboljšanje življenjskega standarda (Vintar Mally, 2003). Ker pomanjkanje izobrazbe omenjene probleme le še povečuje, smo posebej izpostavili skupino prebivalcev s prvo in drugo stopnjo izobrazbe med vsemi registriranimi brezposelnimi, saj je to skupina, ki zelo težko najde primerno zaposlitev (Vintar Mally, 2003; Pečar, 2002).

Pomemben vidik trajnostnega razvoja je tudi odpravljanje razlik med spoloma, zato je predstavljen tudi kazalec delež žensk med registriranimi brezposelnimi. Gre za skupino žensk, ki je iz različnih vzrokov prikrajšana za osnovni vir preživetja in potencialno bolj izpostavljena revščini in socialni izključenosti (Vintar Mally, 2003).

\section{DEMOGRAFSKE IN SOCIALNE ZNAČILNOSTI OBČIN SPODNJEGA POSAVJA}

Leta 2011 je na območju Spodnjega Posavja živelo 70.167 prebivalcev, kar znaša dobra dva odstotka več kot leta 2002. Znotraj obravnavanega območja je imela leta 2011 največ prebivalcev občina Krško (25.867), sledita občini Brežice in Sevnica, daleč najmanj občanov ima občina Kostanjevica na Krki (2404). Primerjalno, glede na leto 2002, lahko ugotovimo trend nizke rasti prebivalstva, značilen za Slovenijo in Spodnje Posavje, tudi v občini Brežice; nasprotno se je število prebivalcev občine Sevnica v zadnjih devetih letih znižalo za slab odstotek. Pri analizi trendov rasti prebivalstva ostalih dveh obravnavanih občin je potrebno upoštevati, da se je 1. 3. 2006 iz občine Krško izločila sedanja občina Kostanjevica na Krki. Zaradi tega se je dejansko število prebivalcev občine Krško med letoma 2002 in 2011 zmanjšalo za okrog 2400 ljudi. Če se omejimo zgolj na prebivalce tistega dela občine Krško, ki jo sestavlja danes, pa lahko ugotovimo med omenjenima letoma nizko rast prebivalstva, medtem ko se je na območju današnje občine Kostanjevica na Krki število prebivalcev zmanjšalo za slab odstotek (SURS, 2012). Zaradi omenjenih teritorialnih sprememb v obravnavanem obdobju so, sicer na nivoju občin pridobljeni podatki, preračunani na današnje prostorsko stanje. V kolikor to ni bilo mogoče, so podatki za občino Kostanjevica na Krki zajeti v okviru občine Krško.

Kazalec 'trend spreminjanja števila prebivalcev' lahko dodatno pojasnimo s pomožnimi kazalci, kot so razmerje med moškimi in ženskami, skupni selitveni prirast prebivalstva ter naravni prirastek. Slednji je bil tako za Slovenijo (-0,6 \%), kot tudi za občine Brežice $(-2,1 \%$ \%), Krško $(-1,4 \%$ \%) in Sevnica $(-1,8 \%$ \%) v letu 2002 negativen. V letu 2010 pa je bil naravni prirastek prebivalstva za Slovenijo pozitiven in je znašal 1,8 \%o. Pozitivno vrednost tega kazalca je v letu 2010 beležila tudi občina Krško (0,8 \%), medtem ko je bil v ostalih treh občinah še vedno negativen ter se je gibal med $-2,8 \%$ v občini Sevnica in $-1,2 \%$ v občini Kostanjevica na Krki (SURS, 2012).

Skupni selitveni prirast na 1000 prebivalcev je bil v letu 2008 za vse štiri posavske občine krepko pod slovenskim povprečjem $(10,9)$; še najvišji je bil v občinah Krško $(4,7)$ in Brežice $(4,2)$. Nekaj več ljudi se je priselilo kot odselilo tudi v občino Sevnica $(0,2)$, medtem ko je bila vrednost tega kazalca za občino Kostanjevica na Krki izrazito negativna $(-3,3)$. 
Večino selitvenega prirasta gre na račun priseljevanja iz tujine, saj za vse štiri občine velja, da so vrednosti selitvenega prirasta na 1000 prebivalcev med občinami izrazito negativne (SURS, 2012).

Med prebivalci Spodnjega Posavja je bilo leta 2002 nekoliko več žensk kot moških (49,4 \%), kar je bilo značilno tudi za Slovenijo $(48,9 \%$ ) in za vse tri na tem območju takrat obstoječe občine: Brežice (49,0 \%), Krško (49,7 \%) in Sevnico (49,4 \%). V letu 2011 se situacija ni bistveno spremenila, čeprav je takrat v Spodnjem Posavju živelo več moških kot žensk (50,2 \%), enako tudi v občinah Krško (51,1 \%) in Sevnica (50,3 \%; SURS, 2012).

Čeprav se je gostota poselitve v Spodnjem Posavju v zadnjih devetih letih povečala s 77,5 na 79,3 prebivalca na $\mathrm{km}^{2}$, je še vedno precej redkeje poseljeno od slovenskega povprečja. Med občinami sta najgosteje naseljeni Brežice in Krško, v katerih se je gostota poselitve v obravnavanem obdobju nekoliko povečala. Bistveno redkeje sta poseljeni občini Sevnica in še bolj Kostanjevica na Krki, kjer je v zadnjih devetih letih, v nasprotju s trendi za Slovenijo in celotno regijo, zaznati zmanjšanje gostote poselitve (SURS, 2012).

Preglednica 3: Število prebivalcev in gostota poselitve

Table 3: Number of inhabitants and population density

\begin{tabular}{|l|r|r|r|r|r|r|}
\hline & $\begin{array}{r}\text { Stevilo } \\
\text { prebivalcev } \\
2011\end{array}$ & $\begin{array}{r}\text { Stevilo } \\
\text { prebivalcev } \\
2002\end{array}$ & $\begin{array}{r}\text { Indeks } \\
2011 / 2002\end{array}$ & $\begin{array}{r}\text { Gostota } \\
\text { poselitve } \\
2011 \\
\left(\text { preb./km }^{2}\right)\end{array}$ & $\begin{array}{r}\text { Gostota } \\
\text { poselitve } \\
2002 \\
\left(\text { preb./km }^{2}\right)\end{array}$ & $\begin{array}{r}\text { Indeks } \\
2011 / 2002\end{array}$ \\
\hline Slovenija & 2.050 .189 & 1.964 .036 & 104,5 & 101,1 & 96,9 & 104,3 \\
\hline Spodnje Posavje & 70.167 & 68.565 & 102,3 & 79,3 & 77,5 & 102,3 \\
\hline Brežice & 24.301 & 23.253 & 104,5 & 90,6 & 86,7 & 104,5 \\
\hline Kostanjevica na Krki & 2404 & 2419 & 99,4 & 41,2 & 41,5 & 99,3 \\
\hline Krško & 25.867 & 25.167 & 102,8 & 90,3 & 87,8 & 102,8 \\
\hline Sevnica & 17.595 & 17.726 & 99,3 & 64,4 & 65,1 & 98,9 \\
\hline
\end{tabular}

Vira/Sources: Popis prebivalstva, gospodinjstev in stanovanj 2002, 2011; SURS, 2012

Skupni koeficient starostne odvisnosti za Slovenijo se med letoma 2002 in 2011 ni bistveno spreminjal, zgolj rahlo povečal. Podobno se je koeficient spreminjal tudi v občini Kostanjevica na Krki. Tudi na območju Spodnjega Posavja in občin Brežice, Krško in Sevnica v omenjenem obdobju ni prišlo do bistvenih sprememb koeficienta, le rahlo se je znižal v omenjenih teritorialnih enotah. Tudi koeficient starostne odvisnosti starejših od 65 let se v obravnavanem obdobju ni bistveno spreminjal, čeprav se je tako v Sloveniji kot v Spodnjem Posavju in vseh štirih občinah nekoliko povečal. Podobno velja tudi za koeficient starostne odvisnosti mladih, ki pa se je v nasprotju s predhodnim kazalcem v vseh obravnavanih prostorskih enotah nekoliko znižal. Na območju Spodnjega Posavja je koeficient starostne odvisnosti mladih leta 2011 znašal malo več kot 20, starejših pa skoraj 25, torej je imelo Spodnje Posavje na 100 delovno sposobnih prebivalcev 20 oseb mlajših od 15 let ter 25 oseb starejših od 65 let. Skupni koeficient starostne odvisnosti je znašal skoraj 
45 - torej je bilo na obravnavanem območju na 100 delovno sposobnih prebivalcev 45 oseb mlajših od 15 let ter starejših od 65 let (Popis prebivalstva, gospodinjstev in stanovanj 2002, 2011; SURS, 2012).

Preglednica 4: Koeficient starostne odvisnosti

Table 4: Coefficient of age factor

\begin{tabular}{|l|c|c|c|c|c|c|}
\hline \multirow{2}{*}{} & \multicolumn{2}{|c|}{$\begin{array}{c}\text { Koeficient starostne } \\
\text { odvisnosti }\end{array}$} & \multicolumn{2}{c|}{$\begin{array}{c}\text { Koeficient starostne } \\
\text { odvisnosti starejših }\end{array}$} & \multicolumn{2}{c|}{$\begin{array}{c}\text { Koeficient starostne } \\
\text { odvisnosti mladih }\end{array}$} \\
\cline { 2 - 7 } & 2011 & 2002 & 2011 & 2002 & 2011 & 2002 \\
\hline Slovenija & 44,3 & 42,9 & 23,9 & 21,0 & 20,5 & 21,8 \\
\hline Spodnje Posavje & 44,8 & 46,0 & 24,9 & 23,3 & 20,1 & 22,7 \\
\hline Brežice & 45,9 & 46,6 & 26,6 & 25,1 & 19,2 & 21,5 \\
\hline Kostanjevica na Krki & 45,0 & 44,2 & 23,6 & 21,3 & 21,4 & 22,9 \\
\hline Krško & 44,0 & 45,8 & 22,9 & 22,3 & 21,1 & 23,5 \\
\hline Sevnica & 44,6 & 45,7 & 24,8 & 22,5 & 19,8 & 23,2 \\
\hline
\end{tabular}

Vira/Sources: Popis prebivalstva, gospodinjstev in stanovanj 2002, 2011; SURS, 2012

Preglednica 5: Izobrazbena sestava prebivalstva v letih 2010 in 2002

Table 5: Educational structure of population in 2010 and 2002

\begin{tabular}{|l|c|c|c|c|c|c|c|}
\hline & \multicolumn{4}{|c|}{2010} & \multicolumn{3}{c|}{2002} \\
\cline { 2 - 8 } & $\begin{array}{c}\text { Osnovna } \\
\text { šola ali } \\
\text { manj (\%) }\end{array}$ & $\begin{array}{c}\text { Srednja } \\
\text { sola (\%) }\end{array}$ & $\begin{array}{c}\text { Višja, } \\
\text { visoka } \\
\text { sola (\%) }\end{array}$ & $\begin{array}{c}\text { Neznano } \\
\text { (\%) }\end{array}$ & $\begin{array}{c}\text { Osnovna } \\
\text { šola ali } \\
\text { manj (\%) }\end{array}$ & $\begin{array}{c}\text { Srednja } \\
\text { šola (\%) }\end{array}$ & $\begin{array}{c}\text { Višja, } \\
\text { visoka } \\
\text { sola (\%) }\end{array}$ \\
\hline Slovenija & 15,1 & 58,3 & 26,1 & 0,5 & 33,0 & 54,1 & 12,9 \\
\hline Spodnje Posavje & 15,7 & 62,2 & 21,0 & 1,1 & 37,9 & 53,0 & 9,1 \\
\hline Brežice & 13,5 & 62,9 & 21,9 & 1,8 & 35,0 & 55,3 & 9,7 \\
\hline $\begin{array}{l}\text { Kostanjevica na } \\
\text { Krki }\end{array}$ & 17,8 & 62,8 & 18,4 & 1,0 & 43,1 & 48,2 & 8,7 \\
\hline Krško & 17,0 & 60,0 & 22,1 & 0,8 & 38,3 & 52,2 & 9,5 \\
\hline Sevnica & 16,4 & 64,4 & 18,5 & 0,7 & 40,6 & 51,7 & 7,7 \\
\hline
\end{tabular}

Vira/Sources: Popis prebivalstva, gospodinjstev in stanovanj 2002, 2011; SURS, 2012

V vseh štirih spodnjeposavskih občinah je leta 2002 prevladovalo prebivalstvo s končano srednjo šolo, kar se sklada tudi s slovenskim povprečjem. Dobra tretjina prebivalcev vsake občine, starejših od 15 let, je imela osnovnošolsko izobrazbo. Delež teh je bil v vseh spodnjeposavskih občinah višji od slovenskega povprečja. Precej pod slovenskim povprečjem pa je bil v Spodnjem Posavju delež prebivalstva s končano višjo ali visoko stopnjo izobrazbe. Tudi leta 2010 je imela večina prebivalstva končano srednjo šolo, delež teh se je glede na leto 2002 celo povečal. Pozitiven je tudi bistven dvig deleža prebivalstva s končano višjo ali 
visoko stopnjo izobrazbe, ki se je tako v Spodnjem Posavju kot tudi v vseh štirih občinah, dvignil za skoraj $10 \%$. Prav tako se je na celotnem območju bistveno zmanjšal tudi delež prebivalstva s končano osnovno šolo ali manj (Popis prebivalstva, gospodinjstev in stanovanj, 2002, 2011; SURS, 2012).

Stopnja registrirane brezposelnosti je januarja 2011 v Sloveniji znašala 12,3 \% in je bila, z izjemo občine Kostanjevica na Krki, nižja kot v spodnjeposavskih občinah. Enaka situacija je bila tudi leta 2002. V primerjavi z letom 2002 je bila stopnja registrirane brezposelnosti tako v Sloveniji kot v vseh štirih občinah Spodnjega Posavja leta 2011 nižja. Najbolj se je zmanjšala v občinah Brežice in Krško, v občini Kostanjevica na Krki je bil upad podoben kot za celotno Slovenijo, v občini Sevnica pa nekoliko nižji (SURS, 2012; Zavod Republike Slovenije za zaposlovanje, 2011; Popis prebivalstva, gospodinjstev in stanovanj 2002, 2011).

Preglednica 6: Stopnja registrirane brezposelnosti

Table 6: Registered level of unemployment

\begin{tabular}{|l|c|c|c|}
\hline \multirow{2}{*}{} & \multicolumn{3}{|c|}{ Stopnja registrirane brezposelnosti (\%) } \\
\cline { 2 - 4 } & Januar 2011 & 2002 & Indeks 2011/2002 \\
\hline Slovenija & 12,3 & 13,8 & 89,1 \\
\hline Spodnje Posavje & n.p. & 16,3 & n.p. \\
\hline Brežice & 13,7 & 17,4 & 78,8 \\
\hline Kostanjevica na Krki & 11,2 & 12,4 & 90,3 \\
\hline Krško & 14,6 & 16,9 & 86,4 \\
\hline Sevnica & 14,0 & 14,6 & 95,9 \\
\hline
\end{tabular}

Viri/Sources: SURS, 2012; Zavod Republike Slovenije za zaposlovanje, 2011; Popis prebivalstva, gospodinjstev in stanovanj 2002, 2011

Preglednica 7: Delež žensk med brezposelnimi ter delež brezposelnih s prvo in drugo stopnjo izobrazbe

Table 7: Amount of women among the unemployed and amount of the unemployed with first and second level of education

\begin{tabular}{|l|c|c|c|c|c|c|}
\hline \multirow{2}{*}{} & \multicolumn{3}{|c|}{ Delež žensk med brezposelnimi (\%) } & \multicolumn{3}{c|}{$\begin{array}{c}\text { Delež brezposelnih s prvo in } \\
\text { drugo stopnjo izobrazbe (\%) }\end{array}$} \\
\cline { 2 - 7 } & $\begin{array}{c}\text { Januar } \\
2011\end{array}$ & $\begin{array}{c}\text { Januar } \\
2010\end{array}$ & $\begin{array}{c}\text { Indeks } \\
2011 / 2010\end{array}$ & $\begin{array}{c}\text { Januar } \\
2011\end{array}$ & $\begin{array}{c}\text { Januar } \\
2010\end{array}$ & $\begin{array}{c}\text { Indeks } \\
2011 / 2010\end{array}$ \\
\hline Brežice & 44,0 & 46,3 & 95,0 & 36,6 & 37,7 & 97,1 \\
\hline Kostanjevica na Krki & 46,0 & 43,6 & 105,5 & 38,8 & 39,3 & 98,7 \\
\hline Krško & 44,3 & 48,4 & 91,5 & 43,3 & 44,0 & 98,4 \\
\hline Sevnica & 47,8 & 55,4 & 86,3 & 41,9 & 42,4 & 98,8 \\
\hline
\end{tabular}

Viri/Sources: SURS, 2012; Zavod Republike Slovenije za zaposlovanje, 2011; Popis prebivalstva, gospodinjstev in stanovanj 2002, 2011 
Delež žensk med brezposelnimi se je med letoma 2010 in 2011 znižal v občinah Brežice, Krško in Sevnica, povečal pa v občini Kostanjevica na Krki. Delež brezposelnih s prvo in drugo stopnjo izobrazbe se je v istem obdobju v vseh štirih spodnjeposavskih občinah nekoliko zmanjšal (SURS, 2012; Zavod Republike Slovenije za zaposlovanje, 2011; Popis prebivalstva, gospodinjstev in stanovanj 2002, 2011).

\section{SKLEP}

Podatki o demografskih in socialnih značilnostih prebivalstva so pomemben vir podatkov o človeških virih kot eni od osnov za izdelavo geografske zasnove trajnostnega razvoja Spodnjega Posavja. V spodnji preglednici so predstavljene želene in dejanske smeri gibanja posameznih kazalcev po občinah ter primerjalno tudi za Spodnje Posavje in Slovenijo.

$\mathrm{Z}$ vidika trajnostnega razvoja na lokalni ravni je zmerna rast prebivalstva, ki je odvisna tako od naravnega kot selitvenega gibanja prebivalstva, ovrednotena pozitivno, saj preprečuje depopulacijo, zaraščanje kulturne pokrajine ter kaže na atraktivnost območja za

Preglednica 9: Želene in dejanske smeri gibanja osnovnih kazalcev demografskih in socialnih značilnosti

Table 9: Desired and actual oscillation directions of basic indicators of demographic and social characteristics

\begin{tabular}{|l|c|c|c|c|c|c|c|}
\hline & $\begin{array}{c}\text { Želena smer } \\
\text { gibanja }\end{array}$ & \multicolumn{5}{|c|}{ Dejanska smer gibanja kazalcev } \\
\hline Kazalci/ območje & & Slovenija & $\begin{array}{c}\text { Spodnje } \\
\text { Posavje }\end{array}$ & Brežice & $\begin{array}{c}\text { Kostanjevica } \\
\text { na Krki }\end{array}$ & Krško & Sevnica \\
\hline $\begin{array}{l}\text { Trendi spreminjanja } \\
\text { števila prebivalcev } \\
2011 / 2002\end{array}$ & Rast & Rast & Rast & Rast & Upad & Rast & Upad \\
\hline $\begin{array}{l}\text { Gostota poselitve } \\
\text { 2011/2002 }\end{array}$ & $\begin{array}{c}\text { Stagnacija } \\
\text { ali upad }\end{array}$ & Rast & Rast & Rast & Upad & Rast & Upad \\
\hline $\begin{array}{l}\text { Koeficient starostne } \\
\text { odvisnosti 2011/2002 } \\
\text { starostne } \\
\text { odvisnosti } \\
\text { starejših }\end{array}$ & Rast & Upad & Upad & Rast & Upad & Upad \\
\hline $\begin{array}{l}\text { Izobrazbena sestava } \\
\text { 2010/2002 }\end{array}$ & Dvig & Dvig & Dvig & Dvig & Dvig & Dvig & Dvig \\
\hline $\begin{array}{l}\text { Stopnja registrirane } \\
\text { brezposelnosti } \\
\text { 2011/2002 }\end{array}$ & Upad & Upad & Upad & Upad & Upad & Upad & Upad \\
\hline $\begin{array}{l}\text { Delež žensk med } \\
\text { brezposelnimi } \\
2011 / 2010\end{array}$ & Upad & n.p. & n.p. & Upad & Rast & Upad & Upad \\
\hline $\begin{array}{l}\text { Delež brezposelnih s } \\
\text { prvo in drugo stopnjo } \\
\text { izobrazbe 2011/2010 }\end{array}$ & Upad & n.p. & n.p. & Upad & Upad & Upad & Upad \\
\hline
\end{tabular}


bivanje. Tako je za Slovenijo, kot tudi za območje celotnega Spodnjega Posavja ter občini Brežice in Krško, med letoma 2002 in 2011 značilna počasna rast prebivalstva, medtem ko je v občinah Kostanjevica na Krki in Sevnica število prebivalcev nekoliko upadlo (Vintar Mally, 2003; SURS, 2012; Popis prebivalstva, gospodinjstev in stanovanj 2002, 2011).

Gostota poselitve kaže na koncentracijo prebivalstva na določenem območju. Z vidika trajnostnega razvoja vrednotimo kot ugodnejši upad gostote prebivalstva ali vsaj stagnacijo. V nasprotju z želeno smerjo gibanja kazalca se je gostota poselitve tako v Sloveniji kot v Spodnjem Posavju ter občinah Krško in Brežice nekoliko povečala, v preostalih dveh občinah pa znižala (Vintar Mally, 2003; SURS, 2012; Popis prebivalstva, gospodinjstev in stanovanj 2002, 2011). Vendar je pri tem kazalcu potrebno upoštevati tudi dejstvo, da obstajajo znotraj občin precejšnje razlike v gostoti poselitve.

Skupni koeficient starostne odvisnosti se je v zadnjih devetih letih nekoliko povečal v celotni Sloveniji in občini Kostanjevica na Krki, medtem ko se je v Spodnjem Posavju in ostalih treh obravnavanih občinah nekoliko znižal.

$\mathrm{Z}$ vidika trajnostnega razvoja, ki vrednoti staranje prebivalstva kot izrazito negativen pojav, je pomemben tudi koeficient starostne odvisnosti starejših od 65 let. Ta se je v zadnjih devetih letih povečal v vseh štirih občinah, koeficient starostne odvisnosti mladih pa zmanjšal, tako da lahko govorimo o neugodni demografski sliki občin (SURS, 2012; Popis prebivalstva, gospodinjstev in stanovanj 2002, 2011).

Dvig izobrazbene sestave prebivalstva Slovenije in vseh štirih spodnjeposavskih občin vrednotimo z vidika trajnostnega razvoja kot izrazito pozitiven pojav, saj višja izobrazba omogoča posameznikom lažje uresničevanje njihovih potencialov in vključevanje na trg dela. Enako pozitivno vrednotimo z vidika trajnostnega razvoja tudi znižanje stopnje registrirane brezposelnosti tako v Sloveniji kot vseh spodnjeposavskih občinah. Vendar pa je potrebno upoštevati tudi dejstvo, da se je ta, kljub občutnemu znižanju, v januarju 2011 še vedno gibala med 10 in 15 \%. Tudi delež žensk med brezposelnimi se je znižal v vseh obravnavanih teritorialnih enotah, z izjemo občine Kostanjevica na Krki, vendar se je leta 2011 še vedno gibal okrog 45 \%. Prav tako je v vseh štirih občinah rahlo upadel delež brezposelnih s prvo in drugo stopnjo izobrazbe, vendar se je leta 2011 še vedno gibal med 36 in 43 \% vseh brezposelnih (Vintar Mally, 2003; SURS, 2012; Popis prebivalstva, gospodinjstev in stanovanj 2002, 2011).

Iz preglednice 9 lahko ugotovimo, da se trendi nekaterih izbranih demografskih in socialnih kazalcev v vseh štirih spodnjeposavskih občinah počasi premikajo v želeni smeri trajnostnega razvoja. Občine Brežice, Krško in Sevnica so uspele obrniti trende v želeno smer pri petih izmed sedmih izbranih kazalcev, občina Kostanjevica na Krki pa pri štirih. Največji problem predstavlja predvsem staranje prebivalstva, ki dolgoročno z vidika načrtovanja nadaljnjega razvoja $\mathrm{v}$ skladu $\mathrm{z}$ načeli trajnosti ni zaželeno. Največji premik $\mathrm{v}$ pozitivno smer so vse štiri občine v zadnjih devetih letih dosegle pri izobrazbeni strukturi prebivalstva. Kljub temu je potrebno upoštevati, da je prehod proti trajnostnemu razvoju dolgoročen proces in da so spremembe v to smer na območju Spodnjega Posavja majhne in počasne. 


\section{Viri in literatura}

Berdavs, J., 2007. Poizkus merjenja trajnostnega razvoja slovenske Istre. Annales: Series historia et sociologia, 17, 2, str. 337-348.

Indeks boljšega življenja. 2011. URL: http://www.oecdbetterlifeindex.org (Citirano 22. 7. 2011).

Indicators of sustainable development. A pilot study following the methodology of the United Nations Commission on Sustainable Development. 1997. Luxembourg, Office for Official Publications of the European Communities, 128 str.

Indicators of sustainable development: Guidelines and methodologies (3rd ed.). 2007. New York, United Nations, 99 str. URL: http://www.uneca.org/eca_programmes/sdd/ events/Rio20/WorkshopSDIndicator/SustainableDevelopmentIndicators.pdf (Citirano 10. 3. 2012).

Občina Brežice. URL: http://www.brezice.si (Citirano 10. 3. 2012).

Občina Kostanjevica na Krki. URL: http://www.kostanjevica.si (Citirano 10. 3. 2012).

Občina Krško. URL: http://www.krsko.si (Citirano 10. 3. 2012).

Občina Sevnica. URL: http://www.obcina-sevnica.si (Citirano 10. 3. 2012).

Pečar, J., 2002. Regionalni vidiki razvoja Slovenije (in poslovanje gospodarskih družb v letu 2000). Ljubljana, Urad Republike Slovenije za makroekonomske analize in razvoj, 74 str. URL: http://www.umar.gov.si/fileadmin/user_upload/publikacije/dz/2001/dz0601.pdf (Citirano 10. 3. 2012).

Plut, D., 2004. Geografske metode proučevanja degradacije okolja. Ljubljana, Filozofska fakulteta, Oddelek za geografijo, 188 str.

Popis prebivalstva, gospodinjstev in stanovanj 2002. URL: http://www.stat.si/popis2002/si/ default.htm (Citirano 10. 5. 2011).

Regionalna razvojna agencija Posavje. URL: http://www.rra-posavje.si (Citirano 19. 8. 2011).

Seljak, J., 2000. Merjenje uravnoteženega razvoja. Doktorsko delo. Ljubljana, Ekonomska fakulteta, 241 str.

Statistični urad Republike Slovenije (SURS). URL: http://www.stat.si (Citirano 2. 3. 2012).

Vintar, K., 2002. Vrednotenje regionalnega razvoja Spodnjega Posavja z vidika sonaravnosti. Geografski vestnik, 74, 2, str. 21-31. URL: http://zgs.zrc-sazu.si/Portals/8/Geografski_vestnik/gv74-2-vintar.pdf (Citirano 2. 3. 2012).

Vintar Mally, K., 2003. Okoljevarstveni vidiki sonaravnega regionalnega razvoja Slovenije. Magistrsko delo. Ljubljana, Filozofska fakulteta, Oddelek za geografijo, 179 str.

Vintar Mally, K., 2006. Prednosti in omejitve uporabe kazalcev sonaravnega razvoja. Dela, 26, str. 43-59. URL: http://www.ff.uni-lj.si/oddelki/geo/publikacije/dela/files/Dela 26/03\%20vintar.pdf (Citirano 2. 3. 2012).

Zavod Republike Slovenije za zaposlovanje. URL: http://www.ess.gov.si (Citirano 1. 9. 2011). 


\section{DEMOGRAPHIC AND SOCIAL CHARACTERISTICS OF THE MUNICIPALITIES OF SPODNJE POSAVJE REGION BASED ON A MODEL OF SUSTAINABLE DEVELOPMENT AT A LOCAL LEVEL}

\section{Summary}

The data about demographic and social characteristics of population is an important piece of information about human sources as one of the basic elements for the preparation of geographically based sustainable development of the Spodnje Posavje region. Desired and actual directions of the oscillation of particular indicators according to the individual municipalities in comparison to the Spodnje Posavje region and Slovenia are shown in Table 10.

Table 10: Desired and actual oscillation directions of basic indicators of demographic and social characteristics

\begin{tabular}{|c|c|c|c|c|c|c|c|}
\hline & $\begin{array}{l}\text { Desired } \\
\text { oscillation }\end{array}$ & \multicolumn{6}{|c|}{ Actual oscillation direction of indicators } \\
\hline Indicators/area & & Slovenia & $\begin{array}{l}\text { Spodnje } \\
\text { Posavje }\end{array}$ & Brežice & $\begin{array}{c}\text { Kostanjevica } \\
\text { na Krki }\end{array}$ & Krško & Sevnica \\
\hline $\begin{array}{l}\text { Trends in } \\
\text { population growth } \\
2011 / 2002\end{array}$ & Increase & Increase & Increase & Increase & Decrease & Increase & Decrease \\
\hline $\begin{array}{l}\text { Population density } \\
2011 / 2002\end{array}$ & $\begin{array}{l}\text { Stagnation } \\
\text { or } \\
\text { decrease }\end{array}$ & Increase & Increase & Increase & Decrease & Increase & Decrease \\
\hline $\begin{array}{l}\text { Coefficient of age } \\
\text { factor 2011/2002 }\end{array}$ & $\begin{array}{c}\text { Decrease } \\
\text { of age } \\
\text { factor } \\
\text { among } \\
\text { older } \\
\text { people }\end{array}$ & Increase & Decrease & Decrease & Increase & Decrease & Decrease \\
\hline $\begin{array}{l}\text { Educational } \\
\text { structure 2010/2002 }\end{array}$ & Increase & Increase & Increase & Increase & Increase & Increase & Increase \\
\hline $\begin{array}{l}\text { Registered level } \\
\text { of unemployment } \\
2011 / 2002\end{array}$ & Decrease & Decrease & Decrease & Decrease & Decrease & Decrease & Decrease \\
\hline $\begin{array}{l}\text { Amount of } \\
\text { women among } \\
\text { the unemployed } \\
2011 / 2010\end{array}$ & Decrease & No data & No data & Decrease & Increase & Decrease & Decrease \\
\hline $\begin{array}{l}\text { Amount of the } \\
\text { unemployed with } \\
\text { first and second } \\
\text { level of education } \\
\text { 2011/2010 }\end{array}$ & Decrease & No data & No data & Decrease & Decrease & Decrease & Decrease \\
\hline
\end{tabular}


According to the aspect of sustainable development at the local level, the moderate population growth, dependent on natural and migratory movement of population, is evaluated positively. It prevents the depopulation and overgrowing of cultural landscape and reflects the attractiveness of the area in terms of the settlement. A slow population growth is characteristic of Slovenia, the whole area of Spodnje Posavje region and the municipalities of Brežice and Krško between 2002 and 2011, while in the municipalities of Kostanjevica na Krki and Sevnica the population somewhat decreased (Vintar Mally, 2003; SURS, 2012; Popis prebivalstva, gospodinjstev in stanovanj 2002, 2011).

The population density indicates the concentration of population at a certain area. According to the aspect of sustainable development, the advantageous element is a decrease in population density or, at least, its stagnation. In contrast to the desired direction of indicator movement, the settlement density in Slovenia, as well as in the Spodnje Posavje region and the municipalities of Krško and Brežice somewhat increased, while in the other municipalities decreased (Vintar Mally, 2003; SURS, 2012; Popis prebivalstva, gospodinjstev in stanovanj 2002, 2011). The fact must also be considered that there are considerable differences related to the population density of certain areas.

The common coefficient of age factor for Slovenia and the municipality of Kostanjevica na Krki somewhat increased in the last nine years, while in the Spodnje Posavje region and three other municipalities, slightly decreased. According to the aspect of sustainable development, evaluating the aging of the population as an extremely negative phenomenon, the coefficient of age factor of people older than 65 years, is also important. In all four municipalities it increased in the last nine years, while the coefficient of age factor of up to fifteen years old people, decreased. We are dealing here with a negative demographic situation of the municipalities (SURS, 2012; Popis prebivalstva, gospodinjstev in stanovanj 2002, 2011).

The increase of the educational structure of Slovenian population and of all four municipalities in the Spodnje Posavje region, may be, according to the aspect of sustainable development, evaluated as an extremely positive element. Higher education enables the individuals to realize their potentials and to find jobs easier.

The decrease of registered level of unemployment may be, in Slovenia, as well as in all the other municipalities in the Spodnje Posavje region, evaluated as positive, according to the aspect of sustainable development. But, the data show that its level was despite considerable decrease still between 10 and 15\% in January 2011. Between 2010 and 2011 the number of unemployed women decreased in all the territorial units except for the municipality of Kostanjevica na Krki, but being still around 45\%. The amount of the unemployed with the first and second level of education slightly decreased in all four municipalities between 2010 and 2011 but being still between 36 and 43\% of all the unemployed (SURS, 2012; Popis prebivalstva, gospodinjstev in stanovanj 2002, 2011).

According to Table 10, we may conclude that the trends in selected demographic and social indicators for all four municipalities in the Posavje region slowly move towards the desired direction of sustainable development. The municipalities of Brežice, Krško and Sevnica managed to turn the movement trends into the desired direction in five indicators out of seven selected, while the municipality of Kostanjevica na Krki in four indicators. The 
essential problem presents the aging of population which is not desired when speaking in terms of further development in accordance with the principles of sustainability. The most important positive change in the last nine years was achieved in the educational level of population in all four municipalities. The transition towards the sustainable development is a long-lasting process and such changes are in the Spodnje Posavje region still small and slow.

(Translated by Dejan Gorše) 